\title{
Protecting children's rights: why governments must be bold to tackle childhood obesity
}

\author{
Oliver T Mytton ${ }^{1,2}$, Claire Fenton-Glynn, ${ }^{3}$ Emma Pawson ${ }^{1}$, Russell M. Viner, ${ }^{4}$ Sally C Davies ${ }^{1}$
}

1. Chief Medical Officer's Office, Department for Health and Social Care, 39 Victoria Street London SW1H OEU.

2. MRC Epidemiology Unit, University of Cambridge Robinson Way, Cambridge CB2 OSL.

3. Faculty of Law, 10 West Road, Cambridge, CB3 9DZ.

4. UCL Great Ormond St. Institute of Child Health, 30 Guilford Street, London WC1N 1EH.

Contact for lead author: oliver.mytton@dhsc.gov.uk

The Chief Medical Officer's independent review of childhood obesity, [Insert report title], is published today.[1] In England levels of childhood obesity are too high, at around 20\% in 10 to 11 year olds.[2] There is widespread public support for action with three ambitious 'chapters' of a national plan from Government.[1,3] Now we need a focus on implementing solutions, and the independent review calls for bold action to improve children's health.

Key to change is always political will. Over centuries the main political parties in the UK have all passed legislation to protect children's health. In the $19^{\text {th }}$ century parliament legislated to prevent children working in mines and factories to prevent accidents and deaths. Since the 1950s, the Clean Air Act, bans on tobacco advertising, compulsory seat belt usage and the introduction of a levy on the manufacturers of sugar sweetened beverages and more have each protected the health of children. Our Politicians acted because society recognised that children were vulnerable and needed protection. Many of these measures were met with resistance at the time, but they quickly became accepted.

Today, high levels of obesity in children is the canary in the coal mine, an early warning that things are wrong in the environment. Too few children have access to healthy affordable food and too few are sufficiently active for health. For today's children, there remain many environmental factors contributing to ill-health: shops and streets flooded with heavily promoted less-healthy food options; advertising and sponsorship, that places less-healthy foods centre stage in young minds; and towns, predominantly traffic dominated, that limit opportunities to walk to school, to ride a bicycle, or simply to play and explore. These issues affect all our children, however, not all children are affected equally. Children who grow up in deprived neighbourhoods tend to be disproportionately affected.

In the past, legislation has been introduced to protect children's 'interests', and to meet their 'needs'. However, we now recognise that government legislation is necessary not simply because we have an obligation to protect vulnerable children, but because children have a 'right' to action. The UN Convention on the Rights of the Child sets out children's rights to protection, education, health and healthcare, shelter and good nutrition. [5] It changed the way children are viewed and treated, as human beings with a distinct set of rights. The Convention, which we the United Kingdom became a party to in 1991, is the most widely ratified international human rights treaty.

Consistent with the scientific evidence that shows the rise in obesity is primarily environmental in origin,[6] a child rights approach requires us to frame childhood obesity as the responsibility of the State, and as an issue that must be addressed across society, rather than providing a solution on a child-by-child basis.

As set out in Box 1, there are five specific strands of the Convention that are relevant to childhood obesity. Article 24 of the Convention states that children have the right to the highest possible 
standard of health, and the United Nations Special Rapporteur on rights and health has made clear that this requires states to address obesity in children.[7] Being legally binding and widely accepted, the Convention gives both a moral and legal accountability to a government's response to childhood obesity.

Article 24 also requires States to 'take appropriate measures to combat disease and malnutrition', in part 'through the provision of adequate nutritious food.' As malnutrition is seen not only as referring to insufficient calories or nutrients but also excess calories, [8] this Article requires the State to take action concerning food production and sale, where this is affecting children's risk of overweight. As outlined in the report this must include regulation and other measures enacted by the State, such as using the taxation system to promote nutrition, restricting the sale of excessively large portions and mandating the content of food.

Article 17 recognises the role of mass media and requires States to publish guidance to ensure that children are protected from information and materials that cause harm. The United Nations Committee on the Rights of the Child has stated that the marketing of less-healthy foods should be regulated, and their availability controlled, particularly where such marketing is focused on children.[9] Consistent with this, the existing evidence base suggests that children's exposure to lesshealthy food advertising prompts children to consume more calories,[10] and influences food preferences and purchasing patterns towards these foods.[11] Cumulatively this can be expected to contribute to excess weight gain and, in some children, overweight or obesity.

Article 27 provides that every child has the right to a standard of living adequate for the child's physical, mental, spiritual, moral and social development. Article 31 relates to a right to play, central to which is physical activity. In order to exercise the right to play, states must ensure access to safe space that is free from inappropriate hazards, with the UN Committee on the Rights of the Child highlighting such issues as overcrowded cities, uncontrolled traffic, congested streets, and lack of green spaces.[12] In contrast to some other countries, the UK has tended to prioritise motorized travel in its towns. Traffic volume and speed create real dangers and perceptions of dangers act as barriers to children walking, cycling and exploring their neighbourhoods.[13]

Finally, and most importantly, Article 3 of the Convention states that in all decisions take by 'administrative authorities or legislative bodies ... the best interests of the child shall be a primary consideration'. This provides a challenge to the approach taken to date in the UK of seeking to balance the commercial interests of food or television companies against children's health. Article 3 emphasizes that when balancing competing interests, children's rights should not be equally weighted against other interests, but must be given additional weight.

Halting and then reversing the rise in childhood obesity is within the grasp of politicians. All children have a right to grow up in a healthy environment and have a fair chance in life, and States have an obligation to put in place policies and legislation to help achieve this. History will not look kindly on today's politicians if they fail to protect our children's rights and our children's health. It is time to address childhood obesity as a 'a Rights Issue'.

Words: 1040 (Target 800-1000) 


\section{Box 1. Summary of key parts of the Convention on the Rights of the Child relevant to childhood obesity}

Article 3: Best interests of a child. The best interests of the child should be the primary consideration in all decisions and actions concerning children. When governments are faced by conflicting priorities (or lobby groups) children must be given priority.

Article 17: Access to information from the media. Every child has the right to reliable information from a variety of sources, especially when this has the potential to impact on their social well-being, and physical and mental health - and governments should encourage the media to provide information that is socially beneficial. Governments must help protect children from materials that could harm them.

Article 24: Health and health services. Every child has the right to the best possible standard of health. Governments must ensure good quality health care, clean water, nutritious food, and a clean environment and education on health and well-being so that children can stay healthy. Richer countries should help poorer countries achieve this.

Article 27. Adequate standard of living. Every child has the right to a standard of living that is good enough to meet their physical and social needs and support their development. Governments must help families who cannot afford to provide this.

Article 31: Leisure, play and culture. Every child has the right to relax, play and take part in a wide range of cultural and artistic activities.

\section{References}

1. Davies S. CMO Child Obesity Independent Review. London; 2019.

2. Office for National Statistics. National Child Measurement Programme, England 2017/18 school year [Internet]. 2018. Available: https://files.digital.nhs.uk/9F/22AF4D/nati-chil-measprog-eng-2017-2018-rep.pdf

3. Department for Health. Childhood obesity: a plan for action, chapter 2 [Internet]. London; 2018. Available: https://www.gov.uk/government/publications/childhood-obesity-a-plan-foraction-chapter-2

4. Evans GW. The Environment of Childhood Poverty. Am Psychol. 2004;59: 77-92. doi:10.1037/0003-066X.59.2.77

5. Assembly UG. Convention on the Rights of the Child [Internet]. UN Doc A/RES/44/25 1989. Available: https://treaties.un.org/doc/Treaties/1990/09/19900902 03-14 AM/Ch_IV_11p.pdf

6. Swinburn BA, Sacks G, Hall KD, McPherson K, Finegood DT, Moodie ML, et al. The global obesity pandemic: shaped by global drivers and local environments. Lancet. 2011;378: 804814. doi:10.1016/S0140-6736(11)60813-1 
7. Grover A. Report of the Special Rapporteur on the Right of Everyone to the Enjoyment of the Highest Attainable Standard of Physical and Mental Health (A/HRC/26/31). 2014.

8. World Health Organization. What is malnutrition? [Internet]. 2015. Available: https://www.who.int/features/qa/malnutrition/en/

9. UN Committee on the Rights of the Child. UN Committee on the Rights of the Child, General Comment on the right of the child to the enjoyment of the highest attainable standard of Health (UN Doc. CRC/C/GC/15, 17 April 2013). 2013.

10. Russell SJ, Croker H, Viner RM. The effect of screen advertising on children's dietary intake: A systematic review and meta-analysis. Obes Rev. 2018; doi:10.1111/obr.12812

11. Cairns G, Angus K, Hastings G, Caraher M. Systematic reviews of the evidence on the nature, extent and effects of food marketing to children. A retrospective summary. Appetite. 2013;62: 209-15. doi:10.1016/j.appet.2012.04.017

12. UN Committee on the Rights of the Child. General Comment on the right of the child to rest, leisure, play, recreational activities, cultural life and the arts (art. 31). 2013.

13. Marzi I, Demetriou Y, Reimers AK. Social and physical environmental correlates of independent mobility in children: a systematic review taking sex/gender differences into account. Int J Health Geogr. BioMed Central; 2018;17: 24. doi:10.1186/s12942-018-0145-9 